\title{
ACID CONTENT OF SNOW FROM A MID-TROPOSPHERE SAMPLING SITE ON MOUNT LOGAN, YUKON TERRITORY, CANADA
}

\author{
by \\ G. Holdsworth \\ (National Hydrology Research Institute, Environment Canada, Calgary, Alberta T3A 0X9, Canada) \\ and E. Peake
}

(Kananaskis Centre for Environmental Research, University of Calgary, Calgary, Alberta T2N 1N4, Canada)

\section{ABSTRACT}

An ice core $103 \mathrm{~m}$ long was extracted in 1980 from an altitude of $5340 \mathrm{~m}$ on the icefield plateau of Mount Logan, Yukon Territory (lat $60^{\circ} 35^{\prime} \mathrm{N}$, long $140^{\circ} 30^{\prime} \mathrm{W}$ ). The firn-ice transition occurs at a depth of $65 \mathrm{~m}$, corresponding to about the year 1880 .

The chemistry of this upper $65 \mathrm{~m}$ is apparently dominated by acid-ion species, the peaks in which are provisionally identified with several documented volcanic events. Although the analyses cover only selected discontinuous intervals, it appears that there is no significant long-term trend in the background acidity level of the precipitation at this location over the past century, in contrast to the results from the North American Arctic and Greenland.

Nitrate ion concentration shows pseudo-seasonal variations, which may be associated with stratospheric-tropospheric interactions, although other seasonally linked mechanisms are possible. This result has also been reported for ice-core sequences from Greenland. Other nitrate pulses are tentatively associated with local volcanic events and a possible meteorite event (the entry of Tunguska in 1908). One of the largest short-term sources of sulfate ions is probably from volcanic activity on the north Pacific rim. Background volcanically-quiet nitrate and sulfate ion concentrations are compared with similar Greenland data in an attempt to throw further light on the origin of the acids.

Since the moisture for this precipitation originates primarily in the Gulf of Alaska, the data has particular relevance to that region. Short-term climatic changes, as reflected by the oxygen isotope $\left(8^{18} \mathrm{O}\right)$ record, show some response to the major volcanic-acid events. The influences affecting the $8^{18} \mathrm{O}$ record are listed but not discussed.

\section{INTRODUCTION}

The monitoring of acidity of precipitation in remote areas of the world is now being undertaken, because the results are expected to be of great significance to the issue of the long-range transport of atmospheric pollutants. Delmas and Aristarain (1978) presented results for snow from the summit of Mount Blanc which showed an increase of $20 \mu \mathrm{eq} 1^{-1}$ in $\mathrm{H}^{+}$concentration of strong acids from 1940 to $1975 \quad(\mathrm{pH}<5.0)$. These measurements excluded the effects of $\mathrm{CO}_{2}$. Dyurgerov and others (1980) measured the pH of snow from 5 to $6 \mathrm{~km}$ altitude in the Pamirs and obtained values of from 6.3 to 6.9 for the years from 1975 to 1977 . The method of measurement was not stated.

Barrie and others (1981) showed that at stations in the Canadian Arctic north of about $70^{\circ} \mathrm{N}$ the acidity of winter aerosols is such that the pH values of snow are in the range from 5.0 to 5.2 in the absence of neutralization by local dust particles. Such values are reported from the snowpack at Barrow, Alaska.

Galloway and others (1982), working within the
Global Precipitation Chemistry Project, reported a mean $\mathrm{pH}$ value of 5.0 for precipitation at Poker Flats, Alaska during 1979-81, although values varied from about 4.1 to 5.6 over about one year. They estimated that the mean natural $\mathrm{pH}$ for the region was probably $>5$.

Koerner and Fisher (1982) reported pH values of recent snow from $2000 \mathrm{~m}$ altitude on the Agassiz Ice Cap, Ellesmere Island in the range from 4.8 to $>6.0$. When seasonal variations are averaged out, a mean value of 5.23 is obtained $(1954-80)$. These $\mathrm{pH}$ values were obtained using a standard instrument without elimination of $\mathrm{CO}_{2}$. The authors deduced from the data that there had been a decrease in $\mathrm{pH}$ at that site since the early 1930s when the general Holocene mean value of 5.48 was assumed to apply.

An ice core $103 \mathrm{~m}$ long was obtained from the icefield plateau of Mount Logan, Yukon Territory. It was originally intended for studies of climatic change but has been used in studies of trace chemistry and the implications for atmospheric processes (Delmas and others unpublished. That study showed, for the period from 1953 to 1966, that the trace chemistry of the snow was dominated by the strong mineral acids $\mathrm{H}_{2} \mathrm{SO}_{4}, \mathrm{HNO}_{3}$ and $\mathrm{HCl}$. The above study has subsequently been expanded in an attempt to cover as much of the last 100 years as possible. Even though the resulting time series contain large gaps, some useful information may still be deduced from them.

Some additional data are presented from a shallow firn core taken from a site near Mount Logan but further inland, where the net accumulation rate is about four times as high. Some comparisons could then be made with, and some extensions made to, comparable data from the Greenland ice sheet presented by Herron (1982[b]).

\section{GEOGRAPHICAL DESCRIPTION OF THE SITES}

Mount Logan (lat $60^{\circ} 35^{\prime} \mathrm{N}$, long $140^{\circ} 30^{\prime} \mathrm{W}$, altitude $5951 \mathrm{~m})$ is situated in the St Elias Mountains, south-west Yukon Territory, within $100 \mathrm{~km}$ of the Pacific Ocean. The upper plateau, from which the cores were obtained in 1980, lies at an average altitude of $5300 \mathrm{~m}$, covering an area of about $20 \mathrm{~km}^{2}$. This plateau is just below the average altitude of the 500 mbar pressure level (Fig.1) Outcrops of granodiorite occur in the immediate vicinity.

The mean annual air temperature at the core site $(5340 \mathrm{~m})$ is expected to be close to $-29^{\circ} \mathrm{C}$, since the mean annual firn temperature at $10 \mathrm{~m}$ is -28.5 and $-28.9^{\circ} \mathrm{C}$, respectively, in two bore holes on the north-west col for the period from 1976 to 1980 . The net accumulation rate has been determined using pole measurements, gross $\beta$-activity, tritium and oxygen isotope profiles (Holdsworth and others 1984) and is close to $380 \mathrm{~kg} \mathrm{~m}^{-2} \mathrm{a}^{-1}$ on average.

A second sampling site (Eclipse) at lat $60^{\circ} 50^{\prime} \mathrm{N}$, long $139^{\circ} 50 \mathrm{~W}$, altitude $3017 \mathrm{~m}$, is also shown in Figure 1. This site is close to outcrops of sedimentary rocks 


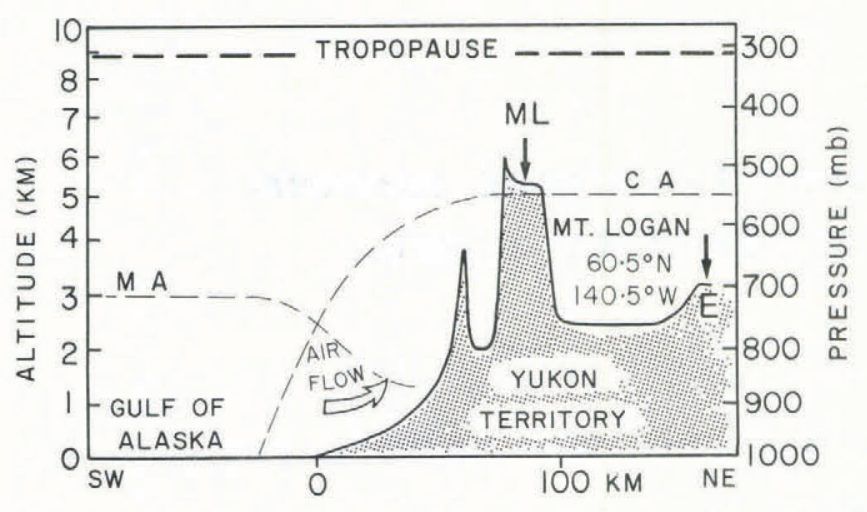

Fig.1. Vertical cross-section through the Gulf of Alaska and the St Elias Mountains showing the sampling sites at Mount Logan (ML) and Eclipse (E). The principal domains of marine aerosols (MA) and continental aerosols (CA) are also shown. The position of the tropopause is an average under stable conditions. (Modified after Junge (1977.)

which include limestone. Cores were obtained from here in 1982 and 1983. The mean annual firn temperature at $10 \mathrm{~m}$ depth is close to $-6^{\circ} \mathrm{C}$, although the mean annual air temperature is expected to be about $-15^{\circ} \mathrm{C}$. The net mean annual accumulation rate determined from oxygen isotope and stratigraphic methods is close to $1500 \mathrm{~kg} \mathrm{~m}^{-2}$ $\mathrm{a}^{-1}$.

The relative positions of the two sampling sites with respect to the Gulf of Alaska and with respect to the tropopause (Fig.1) is relevant to the discussion on the concentrations of acid anions within the two cores. Both sites receive precipitation mainly from the Gulf of Alaska, which is a highly dynamic climatic domain characterized by rapid cyclogenesis and extremely high annual precipitation. The site on Mount Logan was selected (a) to benefit from the substantially lower accumulation rates there, (b) to ensure that a dry and, hence, clean hole could be drilled, and (c) to obtain climatic and other atmospheric information at the 500 mbar height, which is one of the standard climatological reference levels. This elevation is also essentially above the level of marine and most continental aerosols (Fig.1).

The sites are thus in a climatic region which cannot be directly related to the relatively close but climatologically quite different Arctic basin region. The latter appears to act as a sink for some of the anthropogenic air pollution originating at mid-northern latitudes, while the Gulf of Alaska/south-west Yukon atmospheric system appears to be characterized by rapid cleansing due to the high precipitation rates.

\section{CORES}

Continuous coring was carried out in 1980 using a Rufli-Rand electro-mechanical core drill (Holdsworth 1984), specially built for the available logistics. Two principal cores were obtained from the north-west col: the C-core and the D-core to depths of 46 and $103 \mathrm{~m}$, respectively.

Core pieces were transferred from the core barrel into $10 \mathrm{ml}$ polyethylene tubing and closed with staples. Core was always handled with plastic gloves. The covered core was inserted immediately into a thick walled cardboard tube which was plugged with metal end caps. Some cores were flown out to Whitehorse in 1980 and kept at $-22^{\circ} \mathrm{C}$ while other cores had to be stored in a snow cave until 1981 before being flown out to Whitehorse. The core averages $\sim 97.5 \mathrm{~mm}$ in diameter and individual pieces are typically $\sim 30 \mathrm{~cm}$ long.

The cores, which were taken less than $1 \mathrm{~m}$ apart on the top of the north-west col, have been meshed using overlapping oxygen isotope time series and the chemical signature of the massive Novarupta (Mount Katmai) acid event of 1912 which occurs in the lowest part of the C-core. Neither core has yet been completely analyzed.

\section{TIME-SCALE ESTABLISHMENT}

The time scale used in this paper has been established on the following bases. (a) Oxygen isotope analyses have been carried out on the entire C-core and from 44 to $65 \mathrm{~m}$ on the D-core. Seasonal oscillations in $6^{18} \mathrm{O}$ are quite marked, near-surface variations reaching $18 \%$ (b) Relatively confident dating of the upper $26 \mathrm{~m}$ of the C-core was carried out using gross $\boldsymbol{B}$-activity levels, tritium concentration and $\delta^{18} \mathrm{O}$ oscillations together (Holdsworth and others 1984). This procedure established a mean net accumulation rate, from which, knowing the density profile and the total ice depth, an approximate theoretical time scale may be established for the deeper ice. (c) Volcanic events of sufficient size cause perturbations in electrolytic conductivity and $\mathrm{pH}$ (Hammer and others 1980) caused by the presence of the common mineral acids. Using the theoretical time scale as a guide these events can be used to date absolutely a particular section of ice. In this way, the 1912 Novarupta (Mount Katmai) event and other less certain events were identified with an overall accuracy of \pm 1 a. Mainly volcanic events from the north Pacific rim seem to be recorded.

\section{ANALYSES}

\section{Electrolytic conductivity and $\mathrm{pH}$ of meltwater}

Samples ranging from 5 to $10 \mathrm{~cm}$ long were cut from the core in a cold room at $-15^{\circ} \mathrm{C}$ in which an air filter unit was operating. Samples were trimmed with a cleaned chisel on an acrylic trough and transferred to polyethylene Whirl-Pak bags and allowed to melt in a clean air enclosure at about $25^{\circ} \mathrm{C}$. In a laminar flow cabinet, the electrolytic conductivity of the sample was measured with a Radiometer CDM 3 conductivity meter, using a CDC 314 conductivity cell, and the $\mathrm{pH}$ of the sample measured with an Orion 399A meter, using initially a 91-03 combination electrode and later a 91-62 electrode designed for use with low-conductivity water. An equilibrium reading was achieved without final stirring of the water sample. It is possible that $\mathrm{pH}$ values obtained using the different electrodes could differ by as much as \pm 0.05 units. The $\mathrm{pH}$ of distilled, deionized water was routinely checked after each calibration and values of from 5.55 to 5.7 were usually found for water with a specific electrolytic conductivity of $<1 \mu \mathrm{S} \mathrm{cm}^{-1}$. This agrees approximately with the expected value for pure water at low altitudes, in equilibrium with atmospheric $\mathrm{CO}_{2}$ (Charlson and Rodhe 1982).

Earlier pH measurements made in Whitehorse with a portable field $\mathrm{pH}$ meter seem to be unreliable and are not given here. This accounts for the large gaps in the $\mathrm{pH}$ record which is now being rebuilt. The measurements given were made in Calgary (mean annual pressure: 889.4 mbar) and are concentrated on the lower part of the core. No attempt has been made to carry out $\mathrm{pH}$ measurements by excluding $\mathrm{CO}_{2}$ except for a section between 10 and $21 \mathrm{~m}$ depth in the $\mathrm{C}$-core processed in Grenoble (Delmas and others unpublished).

The $\mathrm{pH}$ measurements are mainly used to identify the larger acid events so that the expensive and time-consuming nitrate, sulfate and chloride ion determinations could be carried out at strategic points.

Koerner and Fisher (1982) obtained some significant results for the eastern Arctic using only $\mathrm{pH}$ and conductivity data, and it is therefore convenient to compare the present partial data with their results. The estimated error in the $\mathrm{pH}$ values given is thought to be about \pm 0.05 units. Since a complete ion balance has not been carried out we have not attempted to compare the measured $\mathrm{pH}$ values with the concentrations of anions that were measured.

\section{Acid anion measurements}

Nitrate

Nitrate concentrations in the meltwater were determined by two instrumental methods: (a) a colorimetric method using a Technicon Auto-Analyser (TAA) and (b) ion chromatography (IC).

For the first method, about $3 \mathrm{ml}$ of sample were used in order to obtain duplicate values. In all cases 


\section{(2). Nitrate}

Figures 5 and 6 show the variation of nitrate and other anions in an upper and a lower section of the Mount Logan core. A limited depth profile covering about two years at the Eclipse site is shown in Figure 7. It is apparent that the background levels of $\left[\mathrm{NO}_{3}^{-}\right]$at the two sites are comparable and that, for the Mount Logan site, the background levels have not risen systematically over the last century.

From this data it is possible to recognize that $\left[\mathrm{NO}_{3}^{-}\right]$ is strongly modulated by several processes.

(a). A seasonal process operates at both sites. The 1981-83 Eclipse cycles are very clear and point to spring or summer peaks, whereas the cycles on Mount Logan are frequently obscured or modified by other processes. The sections where the seasonal oscillations are best developed are between 10 and $21 \mathrm{~m}$ (Delmas and others unpublished), 47.5 to $54 \mathrm{~m}$ and 61 to $66 \mathrm{~m}$, although they would be unreliable for annual layer differentiation if used independently.

(b). According to Foley and Ruderman (1973), atmospheric nuclear weapons tests (between 1951 and 1980) generate and introduce significant quantities of NO into the stratosphere. This is a precursor gas for $\mathrm{HNO}_{3}$ which is contained in the precipitation. For the interval from 10 to $21 \mathrm{~m}$ (representing 1953 to 1966) (Delmas and others unpublished), $\left[\mathrm{NO}_{3}^{-}\right]$concentrations show an elevated background which seems to correspond to the smoothed background variations in gross $\boldsymbol{\beta}$-activity. These have been correlated with contemporary tests of nuclear weapons (Holdsworth and others 1984). Furthermore,

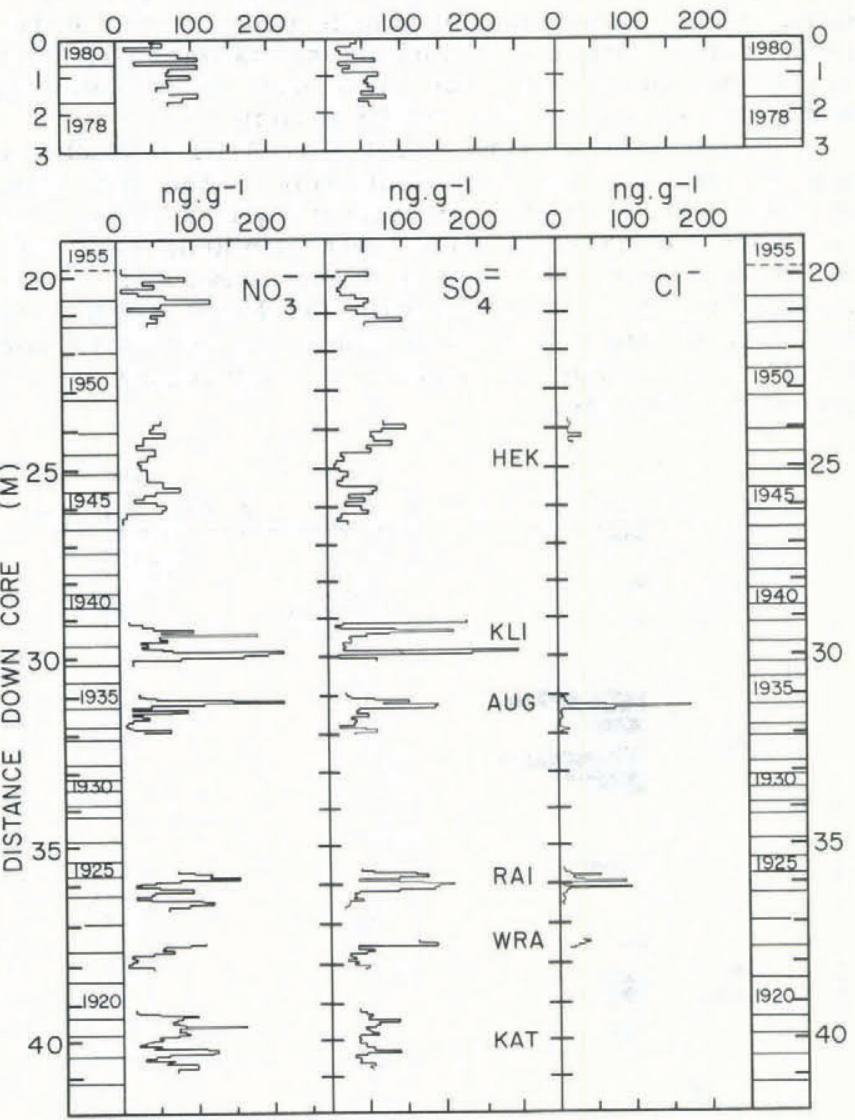

Fig.5. Plot of $\left[\mathrm{NO}_{3}^{-}\right],\left[\mathrm{SO}_{4}^{2-}\right]$ and $\left[\mathrm{Cl}^{-}\right]$from 0 to $3 \mathrm{~m}$ in the D-core and from 20 to $40.8 \mathrm{~m}$ in the C-core. The data for 1953 and 1954 are part of a longer series (to 1966) and were provided by CNRS (Grenoble). These data are shown for comparison with data provided by the Kananaskis Centre for Environmental Research, University of Calgary. Volcanic events are marked as on Figure 2, and, in addition, WRA: Mount Wrangell, Alaska (C Benson private communication). The Icelandic events (HEK: Hekla, and KAT: Katla) are marked but no positive identification is claimed.

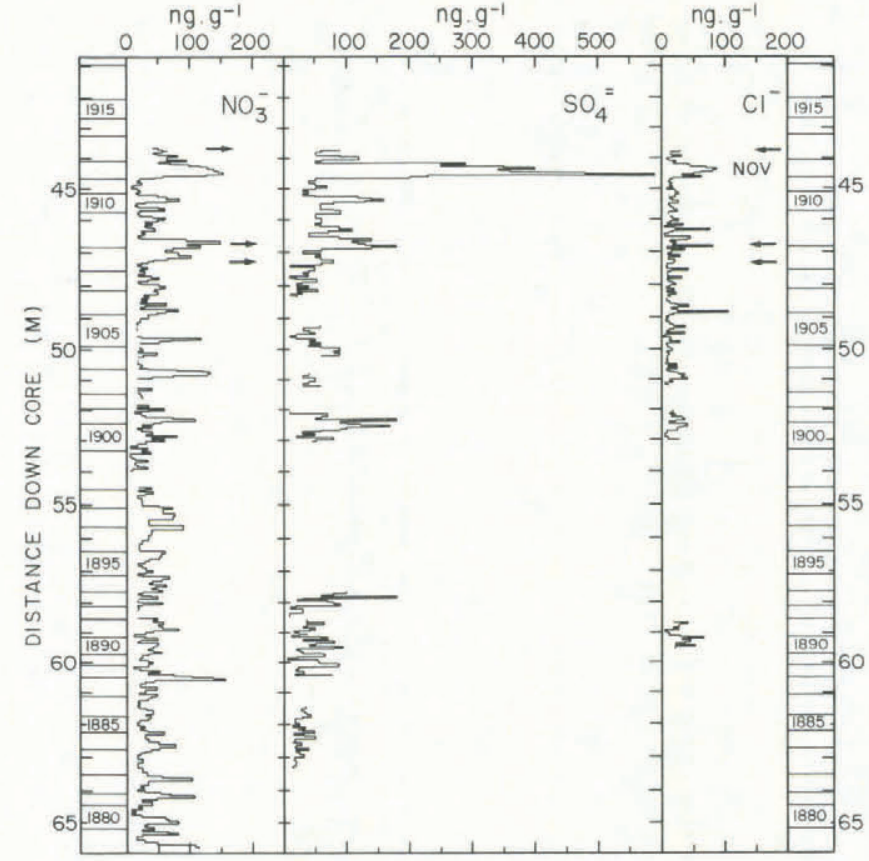

Fig.6. Continuation of data presented in Figure 5 including the D-core from 43.6 to $65.8 \mathrm{~m}$. Arrows indicate positions of particulate peaks tentatively identified with the major acid events occurring at about $1908-09$ and 1912.

several of the peaks in nitrate coincide in time with the peaks in gross $\boldsymbol{\beta}$-activity, and, significantly, the maximum $\left[\mathrm{NO}_{3}^{-}\right]$peak for this era occurs in 1963. The average $\left[\mathrm{NO}_{3}^{-}\right]$concentration in this period is about $12 \%$ higher than for a similar length of time in a volcanically quiet period (Fig.6).

(c). Volcanic eruptions along the north Pacific rim are thought to be responsible for some of the nitrate spikes in the time series. This is certainly true for the 1912 Novarupta (Mount Katmai) eruption which has proved an unequivocal chemical signature in the ice core (Figs.3 and $6)$. The $\left[\mathrm{NO}_{3}^{-}\right]$levels reached four times the background values for a significant fraction of the 1912 interval. Moreover, the shape of the perturbation is compatible with a sudden injection of $\left[\mathrm{NO}_{3}^{-}\right]$and a slow decay, which suggests fallout of stratospheric aerosols.

Other nitrate pulses in the series are provisionally identified with a specific volcanic eruption (Figs.5 and 6), using Simkin and others (1981) as a reference. Use was also made of $\mathrm{pH}$, conductivity, other anion and particulate data.

\section{(3). Sulfate and chloride}

The $\left[\mathrm{SO}_{4}^{2-}\right]$ and $\left[\mathrm{Cl}^{-}\right]$data (Figs.5 and 6) have been determined mainly across known or suspected volcanic intervals and the series are extremely gapped. Nevertheless, the data have been useful in lending support to the preliminary identification of volcanic events. Herron (1982[b]) has shown the often characteristic signatures of a number of volcanic events in terms of the pulses of $\left[\mathrm{SO}_{4}^{2-}\right],\left[\mathrm{Cl}^{-}\right]$and $\left[\mathrm{F}^{-}\right]$but, with the exception of one case, not [ $\left.\mathrm{NO}_{3}^{-}\right]$. This may be a significant observation in terms of the differential transport of volcanic gases and derived acids. Usually, but not invariably, volcanically contaminated snow contains $\left[\mathrm{SO}_{4}^{2-}\right]$ concentrations in the highest proportion, followed by $\left[\mathrm{Cl}^{-}\right]$ or $\left[\mathrm{NO}_{3}^{-}\right]$in similar amounts, and then $\left[\mathrm{F}^{-}\right]$which is lowest.

Background levels of $\left[\mathrm{SO}_{4}^{2-}\right]$ appear not to have changed substantially over the past century.

Limited $\left[\mathrm{SO}_{4}^{2-}\right]$ analyses for the Eclipse site were carried out. From these data an average value was obtained for the purpose of comparing ionic concentrations with altitude and precipitation rate at different sites. 


\section{(4). Particulates}

Particulate data were obtained for two intervals: between 24 and $37 \mathrm{~m}$ in the C-core and between 43 and $60 \mathrm{~m}$ in the D-core. The raw data are not presented here Instead, prominent peaks found in the particulate data are marked on Figures 5 and 6 as arrows, which are appropriately identified in the figure captions. The particle counts reveal an unusual range of concentrations ranging from $10^{4}$ to over $10^{6}$ particles $>1 \mu \mathrm{m} \mathrm{ml^{-1 }}$. There appears to be pseudo-annual spikes in the data.

Two non-volcanic intervals of 27 to $28 \mathrm{~m}$ and 44.8 to $45.2 \mathrm{~m}$ were sampled and found to contain the lowest particulate counts.

\section{DISCUSSION OF RESULTS}

From the limited data on $\mathrm{pH}$ and anions, and the more continuous data on electrolytic conductivity, we conclude that recent snow in the St Elias Mountains is not, on average, any more acidic than snow deposited over the last century. The absence of a long-term trend in the data over this period implies that there is no detectable anthropogenic input of major acid ions (sulfate and nitrate).

The overall data suggest that any significant influence of volcanically derived acids on the chemistry of snow is very short-term. It is likely that only the north Pacific rim volcanoes cause most of these acid signatures, the largest and most definite of which was the 1912 eruption of Novarupta (Mount Katmai). Further processing of the core will reveal whether several earlier volcanic events of global significance are recorded in the core.

Relatively rapid recovery from these polluting events indicates the efficiency of the local north Pacific troposphere in terms of cleansing processes. Thus the apparent absence of evidence for an anthropogenic acid trend originating from the Asiatic industrial complex is hardly unexpected (Rahn 1981). This result contrasts with the snow and ice chemistry data for the much lower sites along the edge of the Arctic Ocean, where anthropogenic components in precipitation have been identified (Barrie and others 1981, Rahn 1981). The climatic conditions in that region, however, are entirely different from the present one.

It should be stressed that this study is incomplete, but it is not expected that further data will alter materially the main conclusions deduced from the results so far. In addition, more detailed sample analyses, resulting in an ion balance, may be desirable (Legrand and Delmas 1984).

Other important but more speculative implications of the data are now discussed.

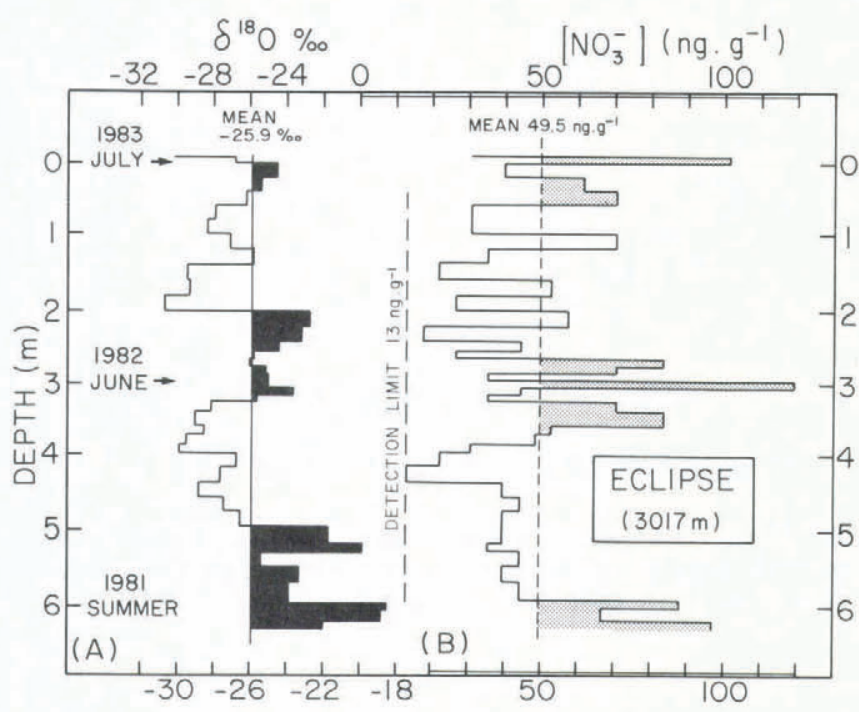

Fig.7. Plot of $8^{18} \mathrm{O}$ and $\left[\mathrm{NO}_{3}^{-}\right]$data for the 1983 Eclipse core.

\section{(1). Atmospheric-precipitation processes}

Seasonal variations in chemical species present an interesting but evidently very complex problem. Herron (1982[a]) discussed the occurrence of seasonal peaks in chemical time series and concluded that for different chemical species and locations, pulses in the concentration of a particular species may occur at different times of the year.

Annual variations in $\left[\mathrm{NO}_{3}^{-}\right]$were recognized in ice-core sequences first from Greenland (Hammer and others 1980, Risbo and others 1981, Herron 1982[b]) and now from the Antarctic (Legrand and Delmas 1984). Nitrate maxima generally occur about mid-year, although this is not invariable, possibly due to the interaction of several processes. Data from Greenland showing long regular sequences in parallel with $\delta^{18} \mathrm{O}$ data indicate that the $\left[\mathrm{NO}_{3}^{-}\right]$peak may tend to occur there in the spring showing essentially the same timing as peak concentrations in other chemical species including particulates (Koerner and Fisher 1982).

The $\left[\mathrm{NO}_{3}^{-}\right]$data for Mount Logan seems to contain significant noise, some of it volcanic, frequently making identification of the exact time of annual peaks uncertain. Data from the Eclipse core shows convincing annual maxima and minima.

There are at least three possible mechanisms which might account for the observed variations in $\left[\mathrm{NO}_{3}^{-}\right]$. (a). A mechanism of biogenic origin (Junge 1963) with maximum activity in the spring or summer. The sites of biological activity would be coastal-marine.

(b). A mechanism involving a photochemical process, possibly within the troposphere (Legrand and Delmas 1984) but with an unknown primary source for the gaseous precursors.

(c). A mechanism controlled by the seasonal variations in the position and speed of rotation of the atmospheric Ferrel cell (Newell and others 1969). In this case the primary source of $\mathrm{NO}_{x}$ is still uncertain, but Huebert and Lazarus (1980) have identified a natural gradient-free layer of $\mathrm{NO}_{\mathrm{x}}$ at 5 to $6 \mathrm{~km}$ altitude between $70^{\circ} \mathrm{N}$ and $55^{\circ} \mathrm{S}$ over western North America and the Pacific Ocean. This layer might have a stratospheric origin. Tropopause folding (Shapiro and others 1984) is one way in which stratospheric air may be injected into the troposphere and vice versa (Shapiro 1980). Risbo and others (1981) suggested seasonal variations in the stratospherictropospheric exchange to account for the seasonal oscillations in their $\left[\mathrm{NO}_{3}^{-}\right]$data from Greenland, which tends to show spring peaks. Shapiro (1980) and Shapiro and others (1984) have described instances of strong tropopause folding in the spring.

\section{(2). Depositional processes near the snow surface}

The data on species concentration discussed above have not been corrected for seasonal variations in precipitation rate because, generally, this is not known. In the case of Mount Logan, meteorological data from stations on either side of the St Elias Mountains show slightly greater precipitation in winter than in summer for Yakutat, Alaska and the reverse for Whitehorse. Therefore it is unlikely that the apparent seasonal variations in the concentration of $\mathrm{NO}_{3}^{-}$can be explained in terms of the precipitation regime. This leads us to a consideration of the effects at different sites of the altitude and the precipitation rates on the concentration of chemical species in the snow. The precipitation rates are derived from the net annual snow accumulation and its density.

Herron (1982[b]) has presented data from before AD 1900 relating concentrations of chloride, nitrate and sulfate to altitude and precipitation rate at several sampling sites in Greenland. Data on chloride concentration are presented in Figure 8 , which shows that for volcanically quiet periods the chloride value lies essentially on the altitude depletion curve described by the equation:

$$
\mathrm{C}=\mathrm{C}_{\mathrm{o}} \exp (-\mathrm{z} / \mathrm{H})
$$

where $\mathrm{C}$ is the concentration of the ion at height $\mathrm{z}$ above 


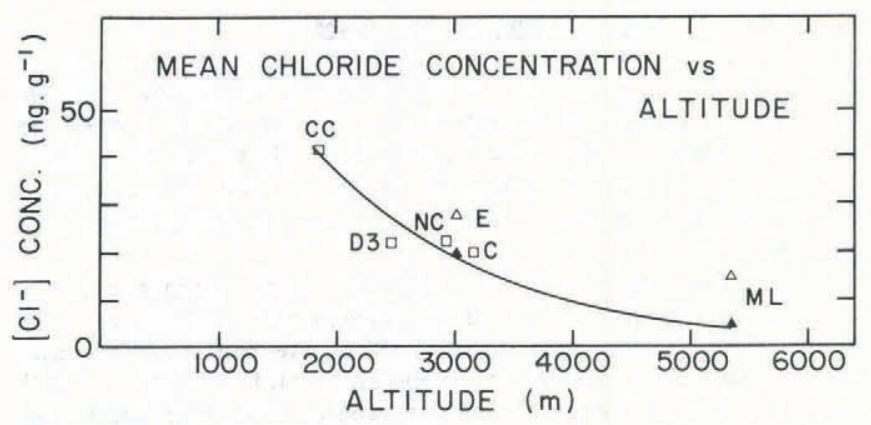

Fig.8. Plot of mean chloride concentration against altitude of snow-sampling site. Greenland data (open squares) are from Herron (1982[b]). Values for the Mount Logan (ML) and Eclipse (E) sites are for the background average in a short volcanically quiet period (filled triangles) and for a longer period (open triangle). The curve is the theoretical altitude depletion for chloride (see text). the sea level. $\mathrm{C}_{0}=135 \mathrm{ng} \cdot \mathrm{g}^{-1}$ and $\mathrm{H}=1.52 \mathrm{~km}$ (Herron $1982[\mathrm{~b}])$. Higher values of $\left[\mathrm{Cl}^{-}\right]$are attributed in several cases to volcanic sources (Figs.5 and 6). The Eclipse value is the mean of 15 values obtained from samples covering summer 1981 to summer 1982. This is an insufficient period of time for obtaining a reliable volcanically quiet background value. We have eliminated the three highest values which are spikes to obtain a mean of $19.6 \mathrm{ng} \cdot \mathrm{g}^{-1}$, which plots virtually on the theoretical curve.

Nitrate concentrations in a volcanically quiet period for Mount Logan and for the period from 1982 to 1983 for Eclipse are plotted versus altitude in Figure 9(a). The points for the Greenland sites are the same as in Figure 8. The Mount Logan point (ML) is comparable to the Dye 3 (D3), Greenland value. Both sites have comparable accumulation rates, which suggests therefore that $\left[\mathrm{NO}_{3}^{-}\right]$is independent of altitude. All points, except Eclipse, lie on an empirical dilution curve described by

$$
\mathrm{C}=\mathrm{C}_{\mathrm{o}} \mathrm{A}^{-\mathrm{n}}
$$

where $\mathrm{C}$ is the concentration of nitrate, $\mathrm{C}_{0}$ is a constant, $\mathrm{A}$ is the accumulation rate and $\mathrm{n}$ is an exponent. Herron

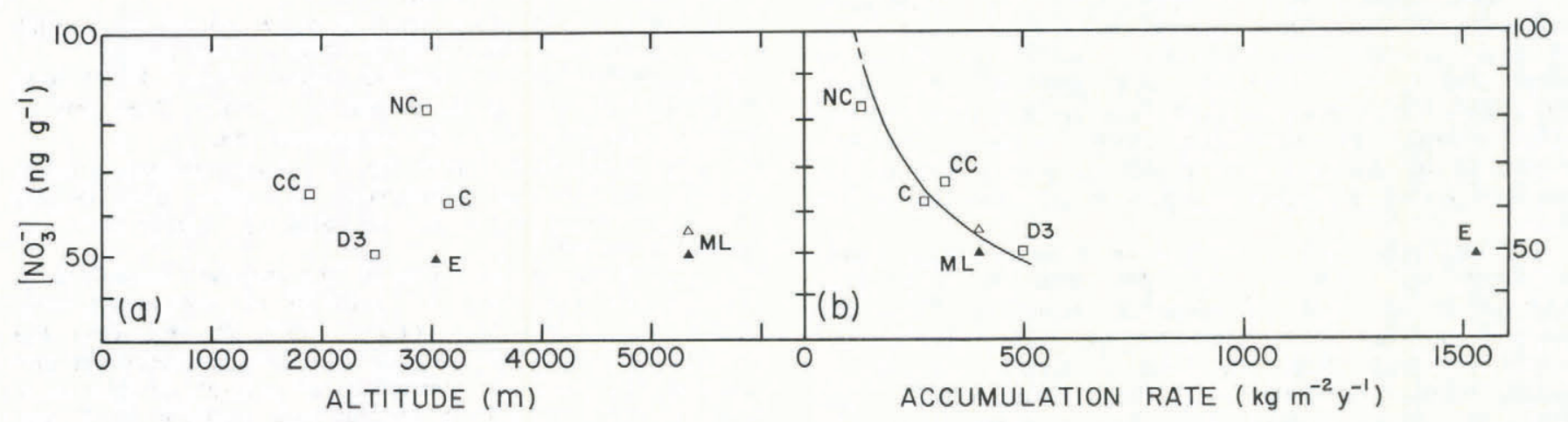

Fig.9(a). Plot of mean long-term concentration versus altitude. Greenland data (open squares) as in Figure 8. Values for the Mount Logan (ML) site are for the long term value in a volcanically quiet period (filled triangle) and for the mean during 1953-66 (CNRS data) (open triangle).
Fig.9(b). Plot of $\left[\mathrm{NO}_{3}^{-}\right]$data against accumulation rate. Empirical dilution curve shown is from Herron (1982[b]).

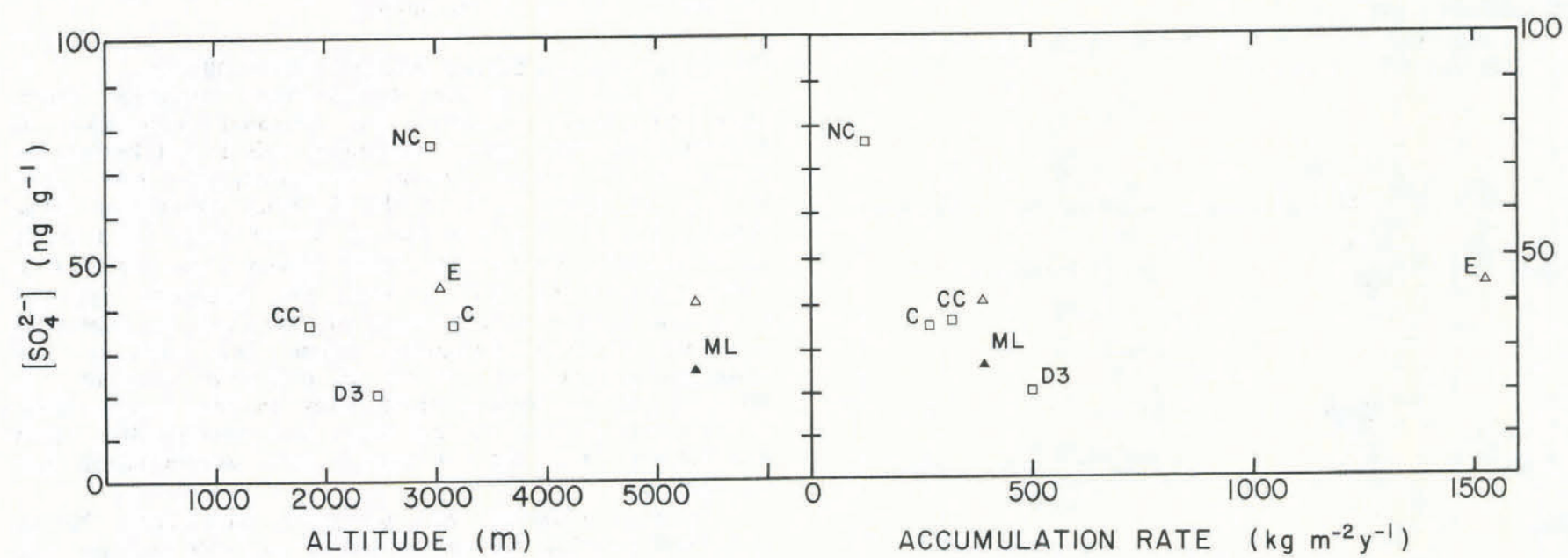

Fig.10(a). Plot of mean non-marine sulfate concentration against altitude. Greenland data (open squares) as in Figures 8 and 9. Values for the Mount Logan (ML) site are the mean for a pre-1900 interval of 10 a (filled triangle) and for 1953-66 (CNRS data) (open triangle). The Eclipse (E) value is the mean for the period summer 1981 - summer 1982 and may be higher than a volcanically quiet background mean. Non-marine sulfate $\equiv\left[\mathrm{SO}_{4}^{2-}\right]-0.14\left[\mathrm{Cl}^{-}\right]$(Herron 1982[b]).
Fig.10(b). The same sulfate data as in Figure 10(a) plotted against accumulation rate. Note apparent inverse relationship in data up to $500 \mathrm{~kg} \mathrm{~m}^{-2} \mathrm{a}^{-1}$. 
(1982[b]) gives a value for $\mathrm{n}=0.5$, but a lower value may be more appropriate. This curve seems to fit the data only to a value of $\mathrm{A} \approx 500 \mathrm{~kg} \mathrm{~m}^{-2} \mathrm{a}^{-1}$ (Fig.9(b)). The Eclipse value could be explained by an increase in efficiency of scavenging with increased accumulation rate or by a higher concentration of nitrate in the atmosphere at Eclipse (compared with Mount Logan) and assuming that precipitation dilution does occur. Until more data are available, the exact mechanisms will remain obscure.

Figure 10(a), following Herron (1982[b]), shows the concentration of non-marine aerosol sulfate plotted against altitude, the Greenland points referring to the same stations as before (Fig.8). It may be seen that the plots of the two St Elias Mountains points compare again with most of the Greenland points except North Central (NC), which, if corrected for the precipitation dilution effect, would plot close to the Dye 3 (D3) level. When the same data are plotted against accumulation rate (Fig.10(b)) the Mount Logan point compares very well with the Greenland data, which seems to show an inverse relationship up to an accumulation rate of about $500 \mathrm{~kg}$ $\mathrm{m}^{-2} \mathrm{a}^{-1}$ (cf. Herron 1982[b]). Again, the Eclipse data point does not conform to any known relationship. To explain the apparent anomaly, we might suppose that either (a) the marine correction is insufficient, or (b) the value itself is based on too short a time period, or (c) there are enhanced processes operating at high precipitation rates to incorporate aerosols or gases into the snow. Sulfate levels for 1981-82 may have been slightly elevated after the eruption of Mount St Helens in 1980. Both Figures 2 and 4 tend to show elevated conductivity and lower $\mathrm{pH}$ values for 1981 and this may have resulted in a value for the background $\left[\mathrm{SO}_{4}^{2-}\right]$ which is too high.

(3). The possible effects of a meteorite entry into the atmosphere

It has been pointed out that the Tunguska meteorite event of June 1908 should have had some effect on atmospheric chemistry, although the exact nature of the effects is still a matter of discussion (Turco and others 1981, Ganapathy 1983, Rasmussen and others 1984).

One of the topics with particular relevance to this study is the possibility that the bolide generated a significant amount of nitric oxide during its entry through the mesosphere and stratosphere. Allowing sufficient time for further oxidation and fallout as $\mathrm{HNO}_{3}$, it might be supposed that a pulse of $\left[\mathrm{NO}_{3}^{-}\right]$could have occurred in the spring of 1909 , although an influx in 1908 is also possible.

A significant pulse of $\left[\mathrm{NO}_{3}^{-}\right]$occurs in the D-core at a depth of about $47 \mathrm{~m}$. The perturbation has two peaks: at $47.2 \mathrm{~m}$ (late $1908 \pm 1$ a) and at $46.8 \mathrm{~m}$ (early $1909 \pm 1$ a). Together, the amount of $\left[\mathrm{NO}_{3}^{-}\right]$is of similar magnitude to the Novarupta pulse just above it (Fig.6). Associated with both these nitrate peaks are two sulfate peaks, the latter one being significantly larger than the earlier one. A chloride perturbation also occurs with the latter event. This is usually characteristic of a volcanic event and normally, but not always, the sulfate concentrations are the highest of all the anions, at least in confirmed cases (Herron 1982[b]). Further, if the bolide was chondritic (Ganapathy 1983) then there is a possibility that significant amounts of $\mathrm{SO}_{2}$ could have been generated, since such meteorites may contain 4 to $5 \%$ sulfur (Rubin 1984). Finally, the particulate concentrations across this interval show that there was an unusually large influx of particles, prominent peaks in which are marked by arrows in Figure 6.

(4). Volcanic gas emission and transport

The Novarupta eruption event occurs in both the Cand the D-cores. Analyses were duplicated across this interval or, in the case of $\left[\mathrm{NO}_{3}^{-}\right]$, triplicated, so the results are considered reliable. We observe that pulses in the different ionic species occur in a definite sequence: nitrate, sulfate, chloride, followed by a peak in particulates (Fig.6). Such a sequence is not seen in the other data or in the data of Herron (1982[b]), except in one case, but no particulate data is given. Either peak emissions of the corresponding gases occurred in this order, or the data reflect the relative residence times of the species in the atmosphere. The delay before peak particulate fallout indicates that the immediate tropospheric particle fallout was very local and the 1913 pulse must then be from stratospheric fallout.

\section{(5). Climatic implications}

It is relevant to point out a climatic connection to the chemical data presented here. The climatic information assumed to be contained in the $\delta^{18} \mathrm{O}$ time series (Figs.2 and 3) presents serious difficulties in interpretation. Whereas seasonal variations in $\delta^{18} \mathrm{O}$ are fairly reliable, long-term averages do not cross-correlate well with station temperature data. Some of the complicating factors to be considered are: (a) variations in the relative proportions of seasonal precipitation, (b) variations in relative removal of snow in different seasons, (c) changes in storm path lengths, (d) changes in the speed of progression of storms, (e) shifts in the maritime versus continental climatic regimes, and (f) changes in the mode and intensity of the jet stream, which may be the fundamental cause of any of the above factors. These and possibly other factors must also influence the content of trace chemicals in the snow.

An interesting observation is the amplitude modulation of $\delta^{18} \mathrm{O}$ after the occurrence of the 1912 Novarupta eruption (Fig.3). The time series also shows a shift towards more negative $\delta^{18} \mathrm{O}$ values, suggesting hemispheric cooling. It is thus of interest to see if a similar phenomenon occurs in the $\delta^{18} \mathrm{O}$ series after the Krakatau eruption of 1883. In fact there is an isotopic cooling after this year and some reduction in amplitude of the $\delta^{18} \mathrm{O}$ oscillations. The chemical evidence for the existence of the Krakatau eruption is unclear, and further analyses need to be done.

Finally, based on a knowledge of the long-term accumulation rate, core density, vertical strain-rate and ice thickness, a time span of $300 \mathrm{a}$ is possible for the $103 \mathrm{~m}$ core. This provides the opportunity to identify the chemical and isotope signatures of the 1815 Tambora volcanic event and the Lakagigar (Laki) volcanic event of 1783-84 (Hammer and others 1980, Simkin and others 1981)

\section{ACKNOWLEDGEMENTS}

The first author wishes to thank the numerous field assistants who helped in the work leading to the retrieval of the ice core. The logistics were handled by the Arctic Institute of North America, and our thanks also to the two pilots for making the operation possible. Some of the nitrate data presented here were provided by the Water Quality Laboratory, Environment Canada and by Chemex Ltd., Calgary.

The particulate analyses were carried out by $M$ Parnandi in the Ice Physics Laboratory of the Polar Continental Shelf Project in Ottawa.

We wish to thank $\mathrm{K}$ Black and $\mathrm{M}$ A MacLean for chemical analyses, $H$ R Krouse and A Shakur for the oxygen isotope data, and $\mathrm{L}$ A Barrie, D A Fisher, $\mathrm{R} \mathrm{M}$ Koerner and M M Herron for helpful comments which resulted in an improved paper.

\section{REFERENCES}

Barrie L A, Hoff R M, Daggupaty S M 1981 The influence of mid-latitudinal pollution sources on haze in the Canadian Arctic. Atmospheric Environment 15(8): 1407-1419

Charlson R J, Rodhe H 1982 Factors controlling the acidity of natural rainwater. Nature 295(5851): 683-685

Delmas R J, Aristarain A 1978 Recent evolution of strong acidity of snow at Mt Blanc. Studies in Environmental Science 1: 233-237

Delmas $\mathrm{R}$ J, Legrand $M$, Holdsworth $G$ Unpublished Snow chemistry on Mount Logan (Yukon Territory, Canada). Paper presented at 5th International Symposium of IAMAP Commission on Atmospheric Chemistry and Global Pollution, Oxford, England, ... 1983

Dyurgerov M B, Yevseyev A V, Sukhova T G 1980 Chemical composition of the snow and ice of the highest glaciers of the Pamirs. Soviet Hydrology 19(1): $50-52$ 
Foley H M, Ruderman M A 1973 Stratospheric NO production from past nuclear explosions. Journal of Geophysical Research 78(21): 4441-4450

Galloway J N, Likens G E, Keene W C, Miller J M 1982 The composition of precipitation in remote areas of the world. Journal of Geophysical Research 87(C11): $8771-8786$

Ganapathy R 1983 The Tunguska explosion of 1908: discovery of meteoritic debris near the explosion site and at the South Pole. Science 220(4602): 1158-1161

Hammer C U, Clausen H B, Dansgaard W 1980 Greenland ice sheet evidence of post-glacial volcanism and its climatic impact. Nature 288(5788): 230-235

Herron M M 1982[a] Glaciochemical dating techniques. In Currie L A (ed) Nuclear and chemical dating techniques: interpreting the environmental record. Washington, DC, American Chemical Society: 303-318 (ACS Symposium Series 176)

Herron M M 1982[b] Impurity sources of $\mathrm{F}^{-}, \mathrm{Cl}^{-}, \mathrm{NO}_{3}^{-}$ and $\mathrm{SO}_{4}{ }^{2-}$ in Greenland and Antarctic precipitation. Journal of Geophysical Research 87(C4): 3052-3060

Holdsworth G 1984 The Canadian Rufli-Rand electro-mechanical core drill and reaming devices. CRREL Special Report 84-34: 21-32

Holdsworth G, Pourchet M, Prantl F A, Meyerhof D P 1984 Radioactivity levels in a firn core from the Yukon Territory, Canada. Atmospheric Environment 18(2): $461-466$

Huebert B J, Lazrus A L 1980 Tropospheric gas-phase and particulate nitrate measurements. Journal of Geophysical Research 85(C12): 7322-7328

Junge C E 1963 Air chemistry and radioactivity. New York, Academic Press

Junge C E 1977 Processes responsible for the trace content in precipitation. International Association of Hydrological Sciences Publication 118 (General Assembly of Grenoble 1975 - Isotopes and Impurities in Snow and Ice): $63-77$

Koerner R M 1977 Distribution of microparticles in a 299-m core through the Devon Island ice cap, Northwest Territories, Canada. International Association of Hydrological Sciences Publication 118 (General Assembly of Grenoble 1975 - Isotopes and Impurities in Snow and Ice): 371-376

Koerner R M, Fisher D A 1982 Acid snow in the Canadian high Arctic. Nature 295(5845): 137-140

Legrand M R, Delmas R J 1984 The ionic balance of Antarctic snow: a 10-year detailed record. Atmospheric Environment 18(9): 1867-1874

Newell R E, Vincent D G, Dopplick T G, Ferruzza D, Kidson J W 1969 The energy balance of the global atmosphere. In Corby G A (ed) The global circulation of the atmosphere. London, Royal Meteorological Society: $42-90$

Rahn K A 1981 Relative importances of North America and Eurasia as sources of Arctic aerosol. Atmospheric Environment 15(8): 1447-1455

Rasmussen K L, Clausen H B, Risbo T 1984 Nitrate in the Greenland ice sheet in the years following the 1908 Tunguska Event. Icarus 58(1): 101-108

Risbo T, Clausen H B, Rasmussen K L 1981 Supernovae and nitrate in the Greenland ice sheet. Nature 294(5842): 637-639

Rubin A E 1984 The Blithfield meteorite and the origin of sulphide-rich metal-poor clasts and inclusions in brecciated enstatite chondrites. Earth and Planetary Science Letters 67(3): 273-283

Shapiro M A 1980 Turbulent mixing within tropopause folds as a mechanism for the exchange of chemical constituents between the stratosphere and troposphere. Journal of the Atmospheric Sciences 37: 991-1004

Shapiro M A, Schnell R C, Parungo F P, Oltmans S J, Bodhaine B A 1984 El Chichon volcanic debris in an Arctic tropopause fold. Geophysical Research Letters 11(5): $421-424$

Simkin T, Siebert L, McClelland L, Bridge D, Newhall C, Latter J H 1981 Volcanoes of the world. Stroudsburg, PA, Hutchinson Ross Publishing Co.

Turco R P, Toon O B, Park C, Whitten R C, Pollack J B, Noerdlinger P 1981 Tunguska meteor fall of 1908: effects on stratospheric ozone. Science 214(4516): 19-23 